\title{
Performance and emissions of diesel engine fuelled with preheated biodiesel fuel derived from crude palm, jatropha, and waste cooking oils
}

\author{
A. Khalid ${ }^{1 *}$, A.S.A. Tajuddin', N. Jaat ${ }^{1}$, B. Manshoor ${ }^{3}$, I. Zaman ${ }^{3}$, S.A.A. Hadi ${ }^{4}$ \\ and R.S. Nursal ${ }^{5}$ \\ ${ }^{1}$ Automotive and Combustion Synergies Technology Group, Advanced Technology \\ Centre (ATC), Faculty of Engineering Technology, Universiti Tun Hussein Onn \\ Malaysia, Parit Raja, Batu Pahat 86400 Johor, Malaysia \\ ${ }^{2}$ Kolej Komuniti Sungai Siput, Sg. Siput, 31100 Perak, Malaysia \\ ${ }^{3}$ Combustion Research Group (CRG), Centre for Energy and Industrial Environment \\ Studies (CEIES) Faculty of Mechanical and Manufacturing Engineering, \\ Universiti Tun Hussein Onn Malaysia, 86400 Batu Pahat, Johor, Malaysia \\ ${ }^{4}$ Mechanical Division, Ipoh City Municipal, State of Perak Darul Ridzuan, Malaysia \\ ${ }^{5}$ Centre of Technology in Marine Engineering (CTME), Marine Engineering \\ Department, Ungku Omar Polytechnic, Ipoh, 31400 Perak, Malaysia \\ *Email: amirk@uthm.edu.my
}

\begin{abstract}
Biodiesel is typically made by chemically reacting lipids of palm, vegetable, and waste cooking oils and animal fat with an alcohol producing fatty acid esters. Biodiesel is not efficient in cold weather and this is biodiesel's major problem. Viscosity has influences on the fuel flow rate and leads to poor fuel atomisation during the combustion process. The aim of this study is to determine the effects of biodiesel temperature in the range fom $40^{\circ} \mathrm{C}$ and $60^{\circ} \mathrm{C}$ on engine performance such as torque, brake power, brake mean effective pressure, and fuel consumption. Three types of biodiesel oil were used (crude palm oil (CPO), waste cooking oil (WCO), and jatropha oil) under biodiesel blending ratio of $5 \mathrm{vol} \%$. A single cylinder four-stroke engine was used and operated under different load conditions of $0 \%$ and $50 \%$ and observed emission of $\mathrm{CO}, \mathrm{CO}_{2}, \mathrm{NOx}$, and $\mathrm{HC}$. The engine operated at $0 \%$ and $50 \%$ dynamometer load conditions and running speeds of the engine of $800 \mathrm{rpm}, 1200 \mathrm{rpm}, 1600 \mathrm{rpm}$, and $2000 \mathrm{rpm}$. The results of this study showed that the heating temperatures in the range from $40{ }^{\circ} \mathrm{C}$ and $60{ }^{\circ} \mathrm{C}$ in $\mathrm{CPO} 10$ produced the highest brake power as well as torque and BMEP. For the experimental results of exhaust emission, the preheated temperature affected the degradation of the exhaust emission. In addition, preheated biodiesel increased the pressure on the cylinder combustion chamber. It can be concluded that the biodiesel preheated blend influences the performance and emission. For CPO biodiesel, the preheated biodiesel decreased $\mathrm{CO}$ and $\mathrm{NO}_{\mathrm{x}}$ while the standard diesel produced the lower emission of $\mathrm{CO}_{2}$ and $\mathrm{HC}$. WCO biodiesel blend produced a lower emission with increasing fuel temperature.
\end{abstract}

Keywords: Biodiesel; diesel engine; emission; engine performance.

\section{INTRODUCTION}

In automotive technology, diesel engines are widely used in heavy machinery industry particularly in the construction, transportation, and agricultural sector. The automotive 
industry is among the biggest contributors to air pollution in the environment. One of the causes of increasing use of biodiesel in heavy vehicles is the source of fuel properties [13]. Biodiesel is typically made by chemically reacting lipids of palm, vegetable, and waste cooking oils with an alcohol producing fatty acid ester [4-6]. Biodiesel and its fuel viscosity are not efficient in cold weather thus influence the fuel-air mixing and ignition process $[2,3,6-8]$. The preheating of biodiesel at different temperatures reduces the viscosity and surface tension which enhances better fuel injection, improves mixture formation, and thereby better fuel atomisation. From the fuel properties, viscosity can affect fuel flow rate and cause poor fuel atomisation during the combustion process [912]. The use of biodiesel or its blend has effects on fuel droplet formation, vaporisation, and airfuel mixing process due to its higher viscosity [13-17]. These effects cause important engine failures such as fuel filter clogging, stuck piston ringg, injector choking, and carbon formation deposits [18-21]. High fuel viscosity also leads to high smoke, HC, and $\mathrm{CO}$ emissions [10, 22-25]. The high viscosity and major chemically bound oxygen component in the biodiesel fuel play as a key element in the combustion process, especially during the fuel-air premixing [26, 27].

Based on the previous studies, jatropha curcas oil (JCO) and waste cooking oil (WCO) can be used in a diesel engine without any modification in the mechanical engine $[12,25,28-30]$. This research also investigates biodiesel by using different blending ratios of WCO. WCO can be identified as alternative sources of raw materials due to the lower price compared to other fuel sources. The implementation of these fuels, its increase of load condition, and preheated biodiesel blend temperature promote more rapid engine performance but exhibit relatively small variations in emission production $[31,32]$. The chemical and physical properties of biodiesel were determined using the ASTM and American Oil Chemists Society (AOCS) standards. For example, jatropha oil kinematic viscosity is high at $35.98 \mathrm{cSt}$ compared to the mineral diesel at $2.44 \mathrm{cSt}$. Fuels with high viscosity tend to form larger droplets of injection which can cause poor combustion [33, 34]. Biofuels in general "result in more atmospheric $\mathrm{CO}_{2}$ pollutants than burning an energy equivalent amount of oil when considering the entire production and consumption cycle". Therefore, the major reduction of $\mathrm{CO}_{2}$ emission should be achieved in road transportation [35, 36]. Further studies on the effects of preheated biodiesel blend fuels from crude palm, jatropha, and waste cooking oils on the performance and emission characteristic were conducted. Preheating is one of the effective methods to reduce the viscosity of biodiesel fuels and its blend, which will gradually decrease as the temperature increases $[37,38]$. The aim of this study is to investigate the effects of heating in variant biodiesel blending ratio on engine performance depending on the properties of the fuel as well as combustion process, injector pressure, and exhaust emission since there are various blends of biodiesels that may be accounted for the contradicting reports with regards to engine performance.

\section{METHODS AND MALERIALS}

\section{Experimental Setup}

The study used biodiesel fuel derived from CPO, JCO and WCO. All the subdivisions of the fuel blending ratio were held fixed at $5 \mathrm{vol} \%$. The petroleum-diesel fuel (DSL) with grade II diesel rated was tested along with the biodiesel blend fuel and nominated as a reference standard fuel. The properties of DSL and all types of biodiesel fuel blends were measured at ambient temperature to conform the MS Standard as shown in Table 1. In this research, the kinematic viscosity of palm oil blend was measured by Viscolite 700 
model VL700-T15. The density properties were measured by Metter Toledo Diamond Scale modelled JB703-C/AF. The water content in biodiesel sample was measured by Volumetric KF Titrator model v20. The flash point was measured by Pensky-Martens PMA 4. This gives the total of eleven different fuels in numbers tested with at room temperature and preheated at the range from $40^{\circ} \mathrm{C}$ and $60^{\circ} \mathrm{C}$. The engine was operated at $0 \%$ and $50 \%$ dynamometer load conditions and running speeds of $800 \mathrm{rpm}, 1200 \mathrm{rpm}$, $1600 \mathrm{rpm}$, and $2000 \mathrm{rpm}$. The maximum load; i.e., 100\% was not considered in the test operation to avoid the exhaustion and failure of the engine as a precaution. The measurements of engine performance data comprised brake power $(\mathrm{kW})$, torque $(\mathrm{Nm})$, brake mean effective pressure $(\mathrm{kPa})$ and volume flow rate (liter/hr) were recorded when the engine speed reached the stable condition. The equipment apparatus for blending process is depicted in Figure 1(a). The three biodiesel blends, WCO, CPO, and JCO were then blended with STD in various concentrations for preparing biodiesel blend. During the blending process, the laboratory scale blending machine was operated at $60{ }^{\circ} \mathrm{C}$ and the mixture was stirred for $1 \mathrm{hr}$. The rotating blade was adjusted to maintain the same speed at $270 \mathrm{rpm}$. The blending temperature was maintained by water jacket surrounding the blending machine.

Table 1. The fuel properties.

\begin{tabular}{|c|c|c|c|c|c|c|c|c|c|c|c|}
\hline & & & & & & Fuel & & & & & \\
\hline $\begin{array}{c}\text { Properti } \\
\text { es }\end{array}$ & $\begin{array}{c}\text { JCO } \\
5 \\
\end{array}$ & $\begin{array}{c}\mathrm{JCO} \\
10 \\
\end{array}$ & $\begin{array}{c}\mathrm{JCO} \\
15\end{array}$ & $\begin{array}{c}\text { WCO } \\
5\end{array}$ & $\begin{array}{c}\text { WCO } \\
10\end{array}$ & $\begin{array}{c}\text { WCO } \\
15 \\
\end{array}$ & DSL & $\begin{array}{c}\mathrm{CPO} \\
5\end{array}$ & $\begin{array}{c}\text { CPO } \\
10\end{array}$ & $\begin{array}{c}\text { CPO } \\
15\end{array}$ & $\begin{array}{c}\text { CPO } \\
20\end{array}$ \\
\hline $\begin{array}{l}\text { Flash } \\
\text { Point } \\
\left({ }^{\circ} \mathrm{C}\right)\end{array}$ & 118 & 118 & 120 & 89.9 & 102.2 & 110 & 71.5 & 85 & 85.5 & 87 & 94.5 \\
\hline $\begin{array}{l}\text { Density } \\
\left(\mathrm{g} / \mathrm{cm}^{3}\right) \\
\text { Water }\end{array}$ & $\begin{array}{c}0.84 \\
6\end{array}$ & 0.848 & 0.849 & 0.836 & 0.84 & 0.833 & $\begin{array}{c}0.82 \\
9\end{array}$ & $\begin{array}{c}0.84 \\
5\end{array}$ & 0.853 & 0.854 & 0.841 \\
\hline $\begin{array}{l}\text { Content } \\
\text { (ppm) }\end{array}$ & 90.1 & 80.4 & 80.2 & 90.4 & 100.1 & 130 & 57 & 140 & 146.1 & 191.9 & 274.7 \\
\hline $\begin{array}{l}\text { Viscosit } \\
\mathrm{y}(\mathrm{cP})\end{array}$ & 4 & 4.6 & 5.3 & 3 & 3.18 & 3.2 & 3 & 4 & 4.1 & 4.3 & 3.1 \\
\hline
\end{tabular}

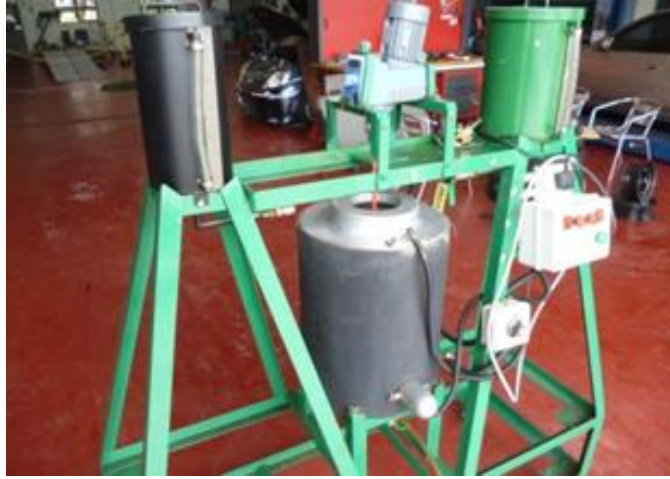

(a) Laboratory scale blending machine

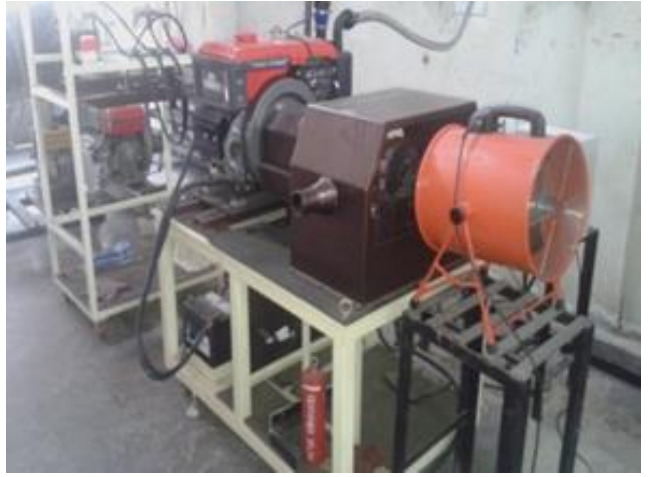

(b) Yanmar Motor Diesel Model Tf120-Ml

Figure 1. Experiment set up. 


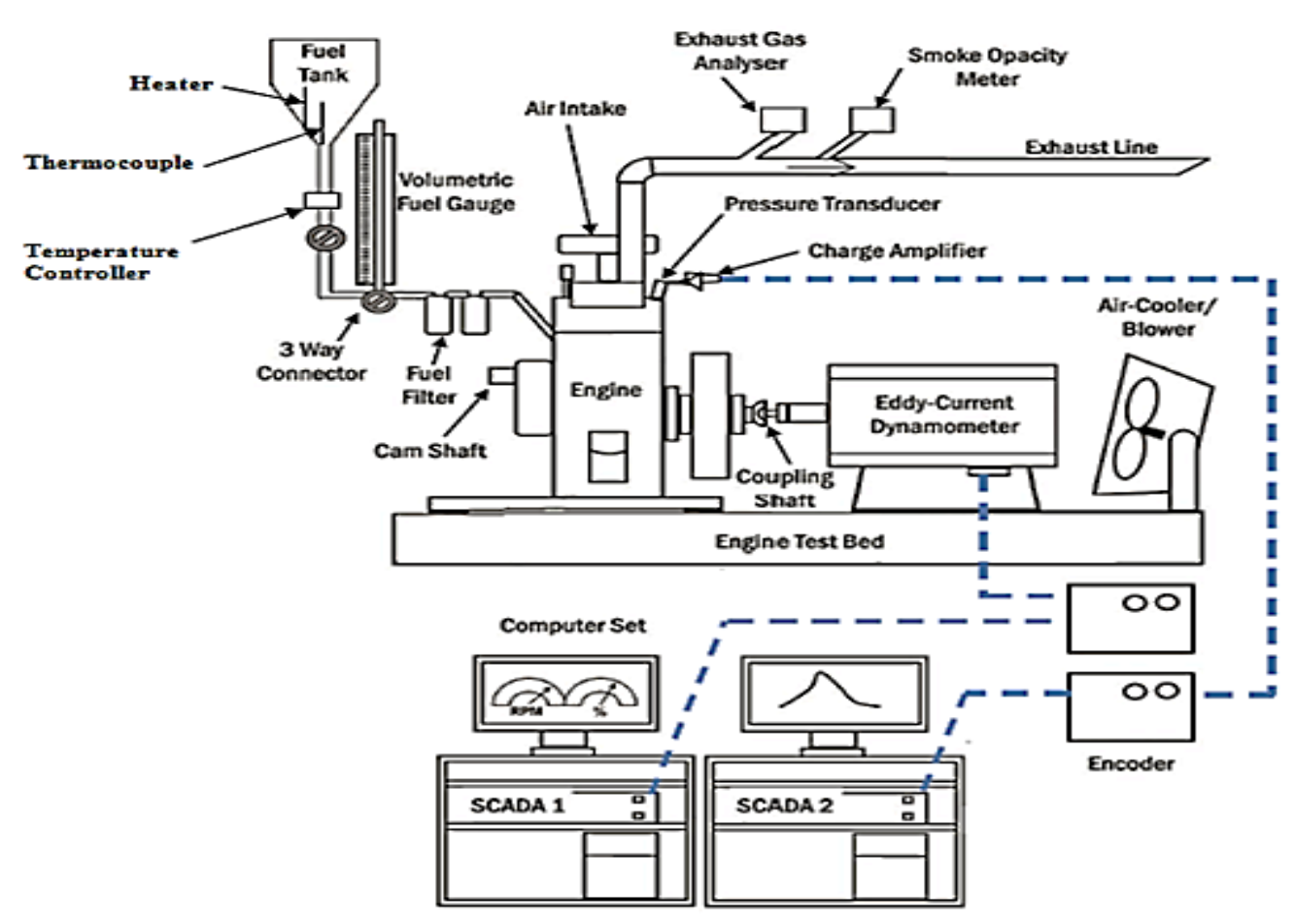

Figure 2. Schematic of experimental setup.

Table 2.Test engine specification.

\begin{tabular}{ll}
\hline Item & Specification \\
\hline Engine Model & TF120-ML \\
Type & 1 cylinder, horizontal, air-cooled, 4 stroke \\
Combustion System & Direct injection \\
Aspiration & Natural aspiration \\
Cylinder Bore x Stroke & $92 \mathrm{~mm}$ x $96 \mathrm{~mm}$ \\
Displacement & 0.638 litre \\
Maximum Output Power & 12 Ps $(8.8 \mathrm{~kW})$ at 2400 rpm \\
Starting System & Manual and auto starting \\
Lubrication System & Complete enclosed forced lubricating system \\
Electrical System & Alternator, 12 V-45 W \\
Fuel Tank Capacity & 11 litre \\
Engine Oil Capacity & 2.8 litre \\
\hline
\end{tabular}

\section{Testing Apparatus}

The engine specification is detailed in Table 2. The experimental setup and schematic apparatus set up are shown in Figures 1(b) and 2, respectively. The engine performance, as well as exhaust emission with respect to biodiesel blends used as fuel, was executed by operating a small diesel engine, model TF120-ML with 0.638-litre capacity, single cylinder horizontal, four-cycle engine with a water-cooled system made by Yammar Motor. The requirement of this engine power is $8.8 \mathrm{~kW}$ at $1 \mathrm{hr}$ due to the lower weight. The parameters measured by this engine were brake power and torque. From the brake power value, the brake effective value means can be shown by the calculation. 
The Eddy current dynamometer which works as load controller was exerted to the engine or engine brake was connected to the engine through a coupling shaft while a specific computer set was integrated and synchronised with the engine particularly the transducer at the engine dynamometer for data acquisition task. The function of this transducer is to capture and analyse the measured data from the dynopack and send to the encoder/data acquisition system (DAQ) before being converted/encoded for computer uses. The setup consists of a single cylinder and four-cycle diesel engine coupled dynamometer with the help of external tank of preheated biodiesels. All these signals were interfaced to computer through signal conditioner and converter for computerisation. Apart from that, the fuel consumption of the engine referred to the durations of the full spent measure at a volumetric fuel gauge which pegged between the fuel tank and pump. Combustion pressure inside the combustion chamber was measured by a piezoelectric pressure transducer. The engine was arranged with the preheated setup with thermostat arrangement as the process was fully arranged with the computerised setup. As the thermostator was arranged, it automatically prefixed the inlet temperature of bio-diesel entering into the engine. The experiment was initiated by using the standard diesel fuel. The computer sets must be started up and put in standby mode while the data acquisition system must be switched on.

Fuel consumption rate is the ratio of a number of kilometres travelled to the number of litres (volumetric fuel consumption) or kilograms (specific fuel consumption) of fuel burned. It is desirable to obtain a lower value of fuel consumption rate which indicates less fuel used by the engine to produce the same amount of work. In the experiment, the volumetric fuel consumption $\left(F C_{V}\right)$ was measured using a volumetric fuel gauge where the fuel consumption was measured by the time to consume $100 \mathrm{ml}$ fuel. The specific fuel consumption $(S F C)$ was measured using the following equation:

$$
S F C=\rho \times F C_{v} \times 10^{-3}
$$

where $S F C$ is the specific fuel consumption in $\mathrm{kg} / \mathrm{h}, \rho$ is the fuel density in $\mathrm{kg} / \mathrm{m}^{3}$ and $F C_{V}$ is the volumetric fuel consumption in litre/h.

Brake specific fuel consumption (BSFC) is defined as the ratio of mass fuel consumption to the brake power which is a convenient way to compare engines of different sizes with regards to the fuel consumption. From the definition of $S F C, B S F C$ can be written by the equation:

$$
\begin{gathered}
B S F C=\frac{\text { Specific fuel consumption }}{\text { Brake power }} \\
B S F C=\frac{S F C}{P_{b}}
\end{gathered}
$$

where BSFC is the brake specific fuel consumption in $\mathrm{kg} / \mathrm{kW} . \mathrm{h}, \mathrm{SFC}$ is the specific fuel consumption in $\mathrm{kg} / \mathrm{h}$ and $P_{b}$ is the brake power in $\mathrm{kW}$.

The engine was coupled to a chassis dynamometer that produced performance parameters. The operating parameters such as loads given during the engine running as well as engine speeds were controlled manually and set by the operator while the overall operation of the engine was automatically monitored using a Supervisory Control and Data Acquisition system (SCADA) by the set of particular integrated computers. The DEWESOFTv7.0 software was used to monitor the input parameters and measure the 
performance of engine and its input parameters while the DYNO-MAX 2010 software was used to analyse the combustion characteristics via the particular computers. Apart from that, the fuel consumption of the engine was calculated manually by using a formula based on the duration of the full spent measure at a volumetric fuel gauge which pegged between the fuel tank and pump. For the emissions, this engine was also installed with combustion analyser probes which can be used to analyse the combustion characteristics as well as ignition behaviour. The exhaust emission was measured with the gas analyser of Autocheck 5 channel exhaust gas analyser model IMR 2800-A. The fuel was filled into the fuel heater tank in specific volume. The power supply to the engine system must be switched on. After the preparation was done, the diesel engine was started manually by controlling the rpm of the engine to working speed. The engine operated in about ten to fifteen minutes under idle speed condition for warming up.

\section{RESULTS AND DISCUSSION}

The properties of diesel, CPO5, CPO10, CPO15, CPO20, JCO5, JCO10, JCO 15, WCO5, WCO10, and WCO15 were tested at three different temperatures and compared with the baseline condition of diesel fuel. Further discussion comprised the analysis of performance and emission characteristics through the blending ratio $5 \mathrm{vol} \%$ and at $0 \%$ and $50 \%$ (medium) dynamometer load conditions. The ND and NP indicate a standard diesel fuel and fuel at room temperature condition, respectively. The P40 and P60 denote the preheated biodiesel at the temperatures of $40{ }^{\circ} \mathrm{C}$ and $60{ }^{\circ} \mathrm{C}$. Figure 3 shows the performance of preheated crude palm oil biodiesel at $5 \%$ blending (CPO5) operated under $0 \%$ and $50 \%$ of load conditions.

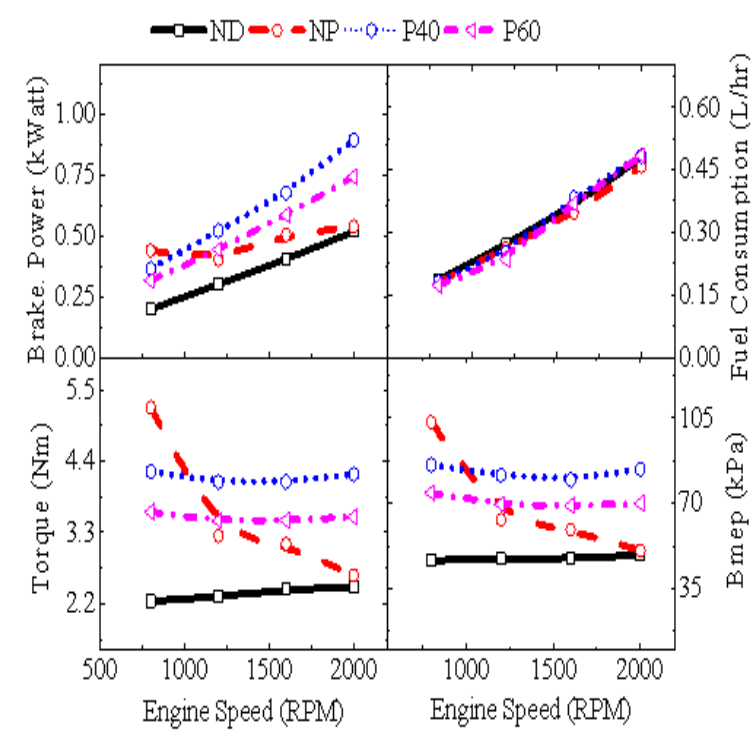

(a) $0 \%$ load conditions

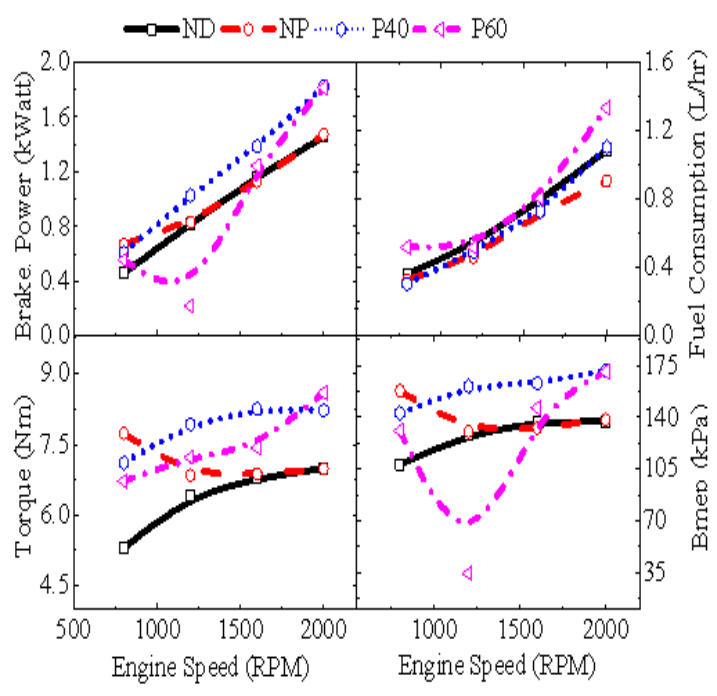

(b) $50 \%$ load conditions

Figure 3. Performance of preheated CPO 5 at $0 \%$ and $50 \%$ load conditions

The blended biodiesel was tested at three different temperatures. The graph plot of torque, brake power, fuel consumption, and brake mean effective pressure versus engine speed. Figure 3(a) shows that brake power increases with the increasing engine speed. In addition, torque remained constant for all engine speeds but decreased gradually for fuel operating under the room temperature. On the other hand, Figure 3(b) illustrates that the CPO5 operated with $50 \%$ load condition. It seems that there was a high fuel 
consumption at P60 when the engine speed increased and higher while running at a high RPM. Thus, it seems that the fuel temperature has a great influence on the fuel-air premixing thus improves the ignition process and combustion characteristics $[22,39,40]$.

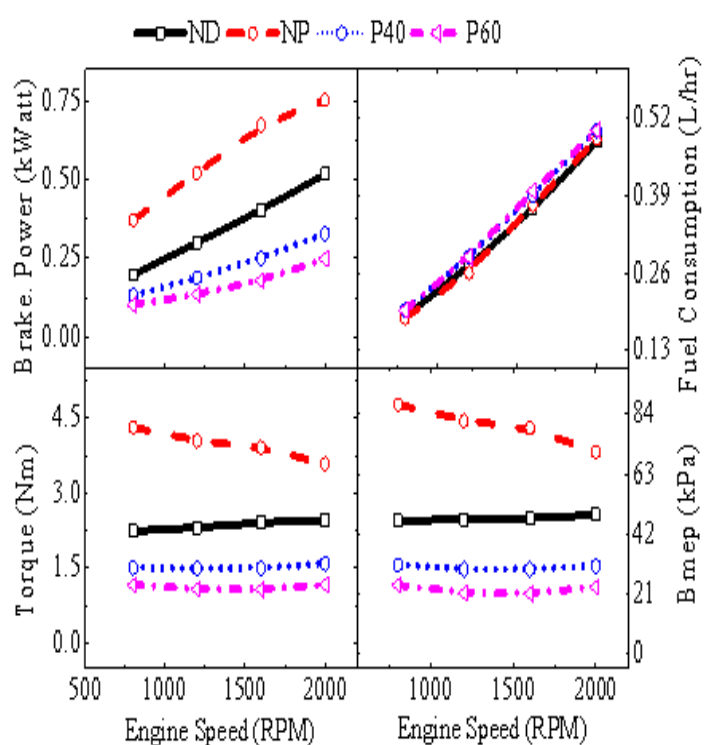

(a) $0 \%$ load conditions

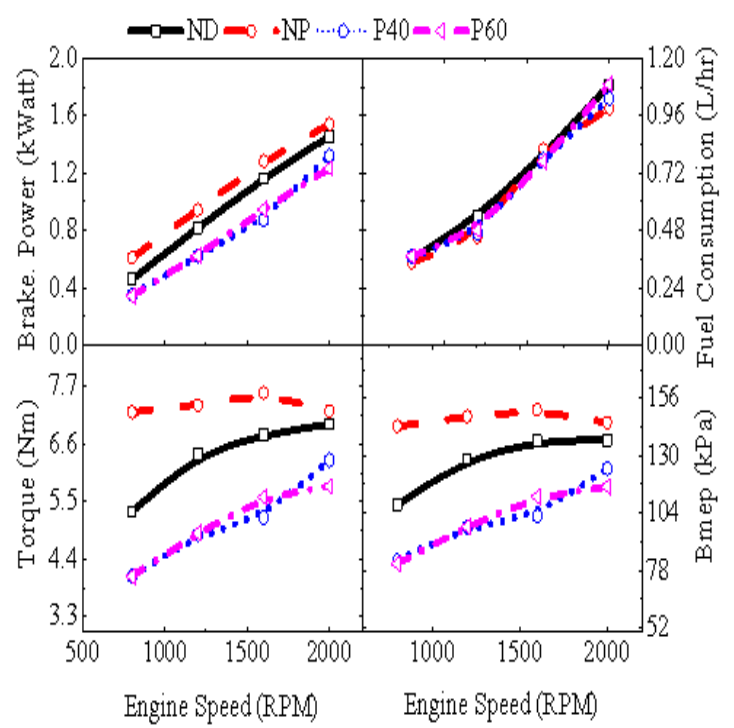

(b) $50 \%$ load conditions

Figure 4. Performances of preheated JCO 5 at $0 \%$ and $50 \%$ load conditions

Figure 4 illustrates the experiment result performance of preheated JCO5 at 0\% and 50\% load conditions. During the combustion at room temperature, fuel, torque, brake power, and brake mean effective pressure showed that the room temperature was higher at both load conditions. Torque and brake mean effective pressure was constant when the engine speed increased except biodiesel at room temperature. This condition slightly decreased when the engine speed increased. Then again, the fuel consumption presented a small different standard diesel and biodiesel at both load conditions. The performance of torque showed a slight increase at 50\% load condition. The preheated biodiesel did not affect the performances of torque, brake power, brake mean effective pressure, and fuel consumption. It seems that the small additional oxygen content due to low blending ratio did not have much influence on combustion [7, 13].

Figure 5 shows the performance of preheated WCO5 at $0 \%$ and $50 \%$ load conditions. The figure indicated that the standard diesel led the performance of torque, brake power, and brake mean effective pressure compared to the blending biodiesel. The preheated $60{ }^{\circ} \mathrm{C}$ showed the lowest of all performance and small changes for fuel consumption.

The investigated effect of preheated biodiesel blending (CPO5) on emission is shown in Figure 6 for $0 \%$ and 50\% load conditions. The graph shows a higher HC emission at a lower engine speed that was reduced to $2000 \mathrm{rpm}$. The preheated biodiesel blend influenced the reduction of $\mathrm{CO}$ and $\mathrm{CO}_{2}$ emissions. The higher engine speed also caused the decrease in $\mathrm{CO}_{2}$ emission. At $2000 \mathrm{rpm}$, the graph shows the increasing $\mathrm{P} 40$ biodiesel blend without preheated biodiesel. 


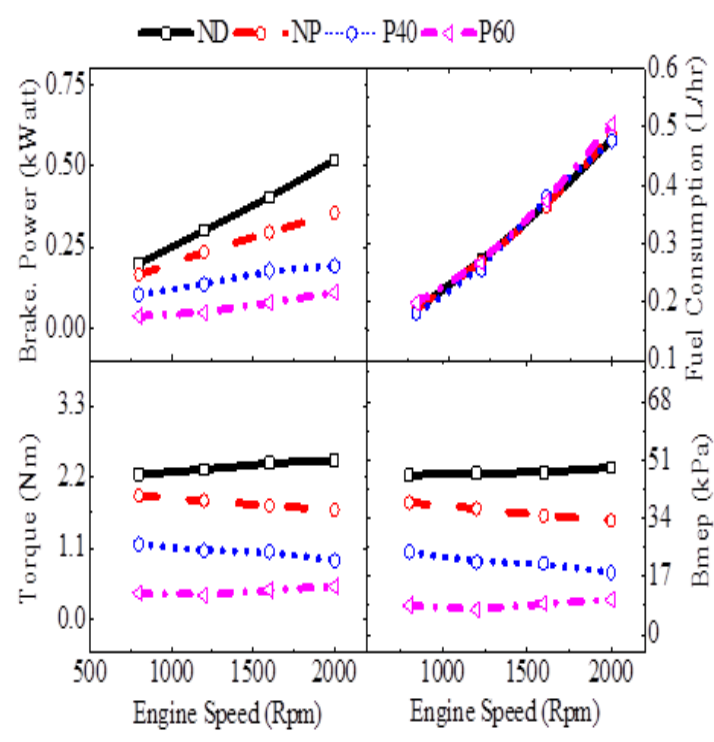

(a) $0 \%$ load conditions

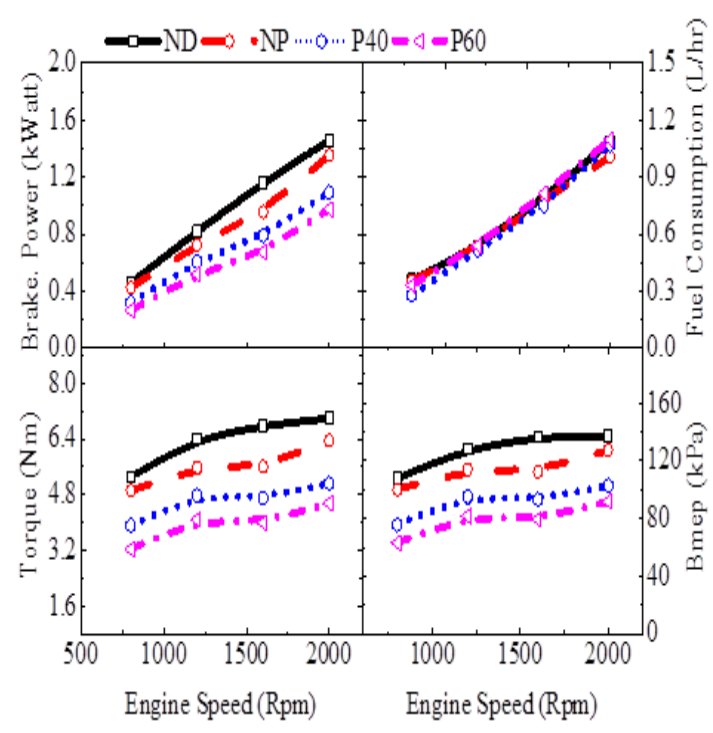

(b) $50 \%$ load conditions

Figure 5. Performances of preheated WCO 5 at $0 \%$ and 50\% load conditions.

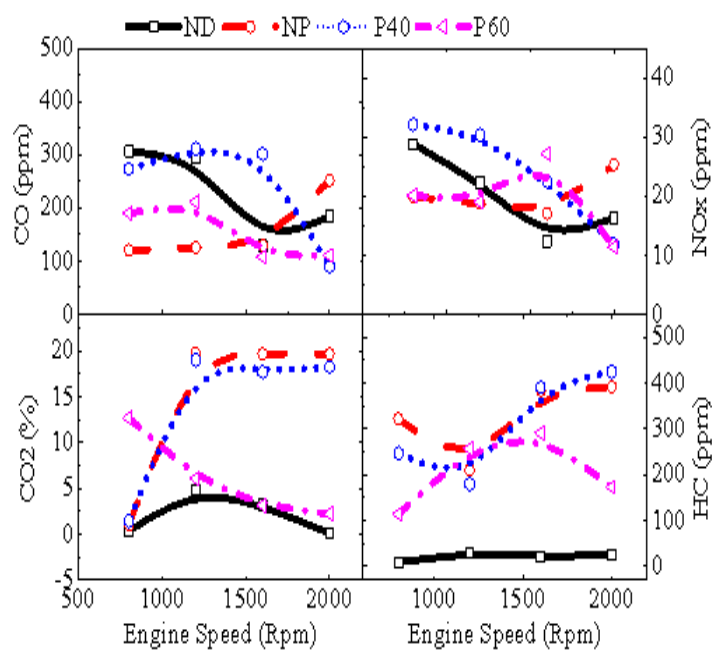

(a) $0 \%$ load conditions

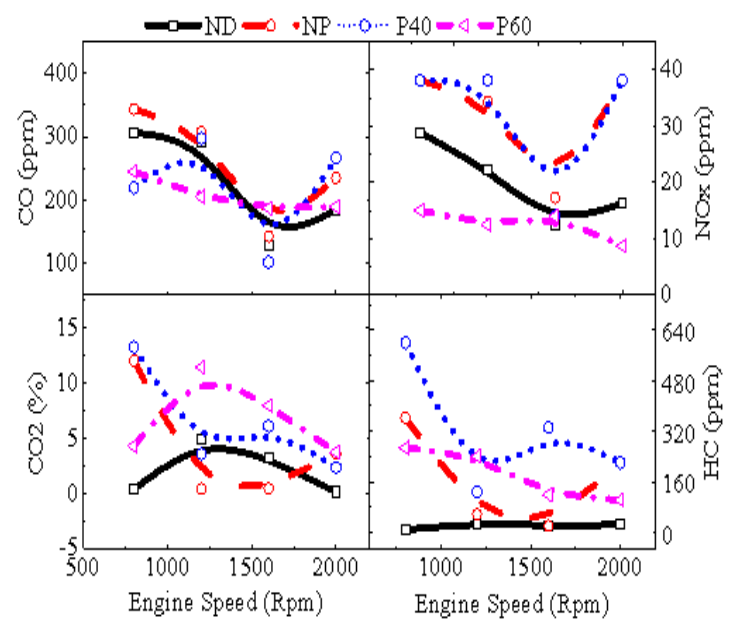

(b) $50 \%$ load conditions

Figure 6. Emission of preheated CPO 5 at $0 \%$ and $50 \%$ load conditions.

The emission of preheated JCO5 at $0 \%$ and 50\% loads is illustrated in Figure 7. The graph trends look similar to both load conditions. The standard diesel produced the lowest emission for $\mathrm{NO}_{\mathrm{X}}, \mathrm{HC}, \mathrm{CO}$, and $\mathrm{CO}_{2}$ for both load conditions. Meanwhile, at the room temperature, biodiesel fuel produced higher value at higher engine speed. Figure 8 shows an emission of preheated WCO5 at $0 \%$ and 50\% load conditions. The increasing load had no effect on the $\mathrm{CO}$ emission. $\mathrm{CO}_{2}$ emission showed a dramatic increase of $\mathrm{P} 40$ WCO5 at $0 \%$ load condition and stable at $50 \%$ load condition. At the room temperature, WCO5 produced a higher $\mathrm{NO}_{\mathrm{x}}$ at $2000 \mathrm{rpm}$ engine speed with higher load condition. 


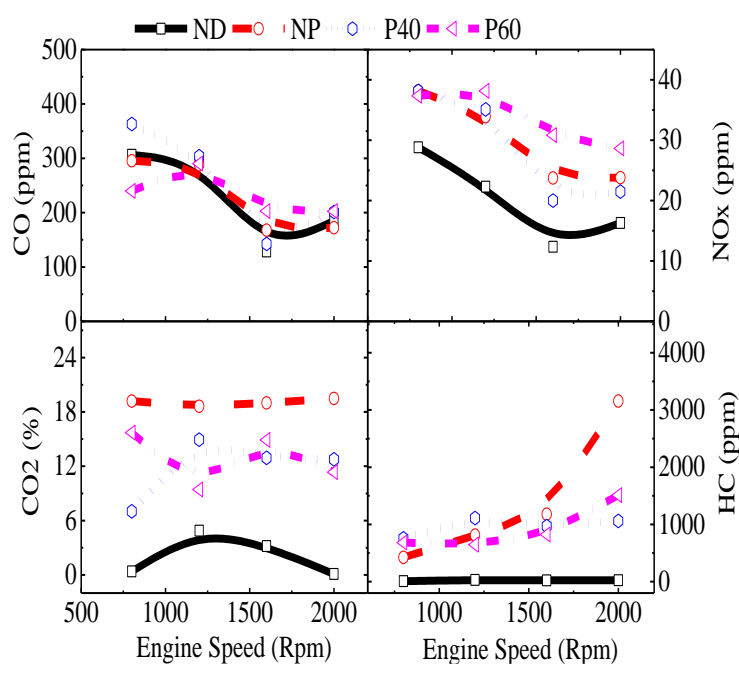

(a) $0 \%$ load conditions

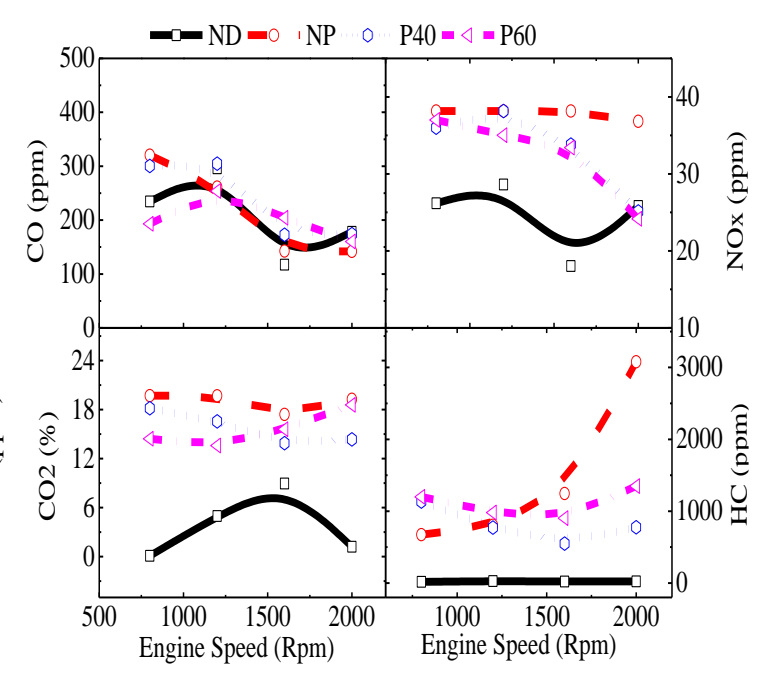

(b) $50 \%$ load conditions

Figure 7. Emission of preheated JCO 5 at $0 \%$ and $50 \%$ load conditions.

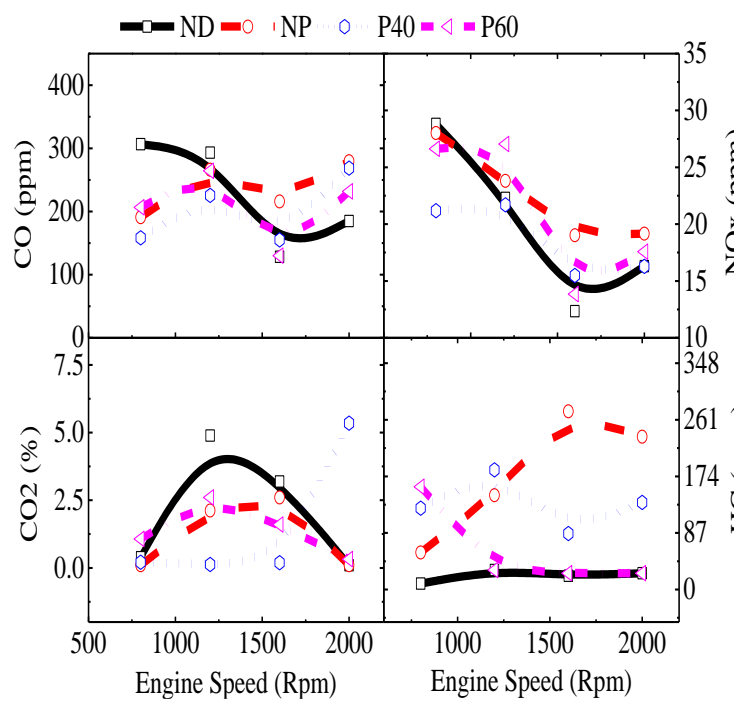

(a) $0 \%$ load conditions

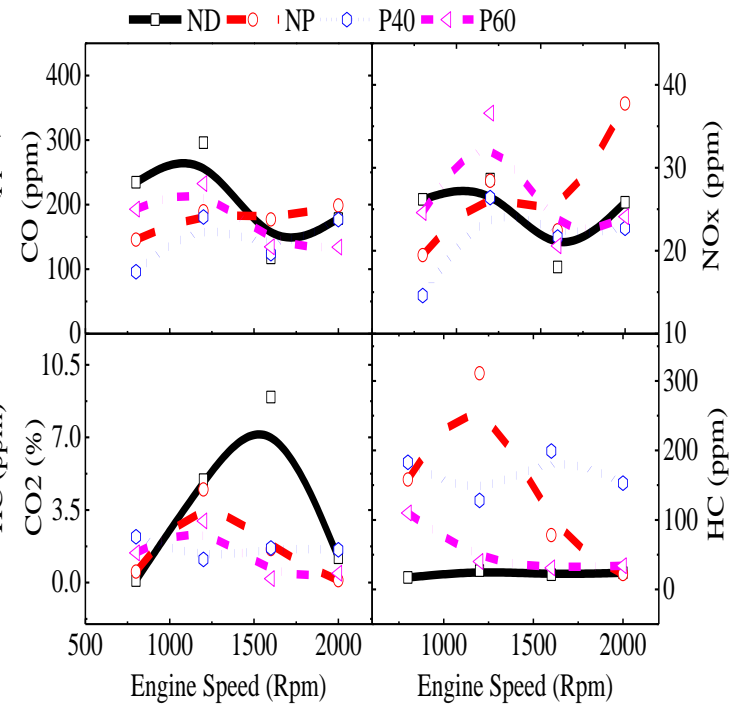

(b) $50 \%$ load conditions

Figure 8. Emission of preheated WCO 5 at $0 \%$ and $50 \%$ load conditions

\section{CONCLUSIONS}

The aim of this experiment is to study the influences of three types of preheated biodiesel fuel blends (CPO, JCO, and WCO) on performance and emissions under load conditions of $0 \%$ and $50 \%$, and adjusted running engine speeds of $800 \mathrm{rpm}, 1200 \mathrm{rpm}, 1600 \mathrm{rpm}$, and $2000 \mathrm{rpm}$. It can be concluded that the biodiesel preheated blend influenced the engine performance and emission. Without using preheated biodiesel, the high load condition $(50 \%)$ of the engine running speed on fuel consumption presented lower average consumption than the standard diesel fuel. However, the preheating also had an effect on the consumption of biodiesels under high load condition $(50 \%)$ which presented lower average consumption than the standard diesel, especially for JCO5. By referring to the performances of torque, brake power, brake mean effective pressure and fuel consumption increase with the increasing the temperature fuel. The value of performance 
was also influenced by engine speed. The preheated biodiesel did not give the same effect on waste cooking oil as the performance in WCO5 was lower than the performance of standard diesel. Under the emission aspect, there are advantages and disadvantages of the preheated biodiesel blends on each emission parameter produced. For CPO biodiesel, preheated biodiesel produced decreased $\mathrm{CO}$ and $\mathrm{NO}_{\mathrm{x}}$ while the standard diesel produced the lower emission of $\mathrm{CO}_{2}$ and $\mathrm{HC}$. WCO biodiesel blends produced a lower emission with increasing fuel temperature.

\section{ACKNOWLEDGEMENTS}

The authors also would like to thank the Ministry of Higher Education Malaysia for supporting this research under Fundamental Research Grant Scheme (FRGS) vot. 1466.

\section{REFERENCES}

[1] Hamada KI, Rahman MM, Ramasamy D, Noor MM, Kadirgama K. Numerical investigation of in-cylinder flow characteristics of hydrogen-fuelled internal combustion engine. Journal of Mechanical Engineering and Sciences. 2016;10:1782-802.

[2] Yasin MHM, Mamat R, Aziz A, Yusop AF, Ali MH. Investigation on combustion parameters of palm biodiesel operating with a diesel engine. Journal of Mechanical Engineering and Sciences. 2015;9:1714-26.

[3] Said NH, Ani FN, Said MFM. Review of the production of biodiesel from waste cooking oil using solid catalysts. Journal of Mechanical Engineering and Sciences. 2015;8:1302-11.

[4] Agarwal AK, Dhar A. Experimental investigation of preheated jatropha oil fuelled direct injection compression ignition engine-part 2: Engine durability and effect on lubricating oil. Journal of ASTM International. 2010;7:1-15.

[5] Alleman TL, McCormick RL, Christensen ED, Fioroni G, Moriarty K, Yanowitz J. Biodiesel handling and use guide 5th edition. U.S Department of Energy; November 2016.

[6] Cahill B. European biofuel standards and regulations biofuels: A positive double impact. February; 2007.

[7] Akasyah M, Mamat R, Abdullah A, Aziz A, Yassin H. Effect of ambient temperature on diesel-engine combustion characteristics operating with alcohol fuel. International Journal of Automotive and Mechanical Engineering. 2015;11:2373-82.

[8] Ibrahim F, Wan Mahmood WMF, Abdullah S, Abu Mansor MR. Numerical investigation of soot mass concentration in compression ignition diesel engine. Journal of Mechanical Engineering and Sciences. 2016;10:2275-87.

[9] Visconti P, Primiceri P, Strafella L, Carlucci AP, Ficarella A. Morphological analysis of injected sprays of different bio-diesel fuels by using a common rail setup controlled by a programmable electronic system. International Journal of Automotive and Mechanical Engineering. 2017;14:3849-71.

[10] Saifuddin N, Refal H, Kumaran P. Performance and emission characteristics of micro gas turbine engine fuelled with bioethanol-diesel-biodiesel blends. International Journal of Automotive and Mechanical Engineering. 2017;14:403049. 
[11] Nayak SK, Mishra PC. Emission from a dual fuel operated diesel engine fuelled with calophyllum inophyllum biodiesel and producer gas. International Journal of Automotive and Mechanical Engineering. 2017;14:3954-69.

[12] Shukri MR, Rahman MM, Ramasamy D, Kadirgama K. Artificial neural network optimization modeling on engine performance of diesel engine using biodiesel fuel. International Journal of Automotive and Mechanical Engineering. 2015;11:2332-47.

[13] Augustine A, Marimuthu L, Muthusamy S. Performance and evaluation of di diesel engine by using preheated cottonseed oil methyl ester. Procedia Engineering. 2012;38:779-90.

[14] Khalid A, Jaat N, Sapit A, Razali A, Manshoor B, Zaman I, et al. Performance and emissions characteristics of crude jatropha oil biodiesel blends in a diesel engine. International Journal of Automotive and Mechanical Engineering. 2015;11:2447.

[15] Adam IK, Aziz ARA, Yusup S. Determination of diesel engine performance fueled biodiesel (rubber seed/palm oil mixture) diesel blend. International Journal of Automotive and Mechanical Engineering. 2015;11:2675.

[16] Vajja SR, Murali R. Performance evaluation of diesel engine with preheated bio diesel with additives. IOP Conference Series: Materials Science and Engineering: IOP Publishing; 2016. p. 012206.

[17] Awad OI, Mamat R, Ali OM, Sidik N, Yusaf T, Kadirgama K, et al. Alcohol and ether as alternative fuels in spark ignition engine: A review. Renewable and Sustainable Energy Reviews. 2017.

[18] Standard A. D6751, standard specification for bio-diesel fuel (b100) blend stock for distillate fuels. West conshohocken, pa: Astm. Automotive fuels-fatty-acid methyl esters (fame) for diesel engines - requirements and test methods. BeuthVerlag, Berlin, Germany; 2008.

[19] Jazair W, Kubo S, Takayasu M, Yatsufusa T, Kidoguchi Y. Performance and emission characteristics of a diesel engine fueled by rapeseed oil bio-fuel. J Mek UTM. 2011;33:32-9.

[20] Karim A, Kartina S. Production of biodiesel from crude palm oil (CPO) and waste cooking oil (WCO) through transesteri fication method/siti kartina abdul karim. Asian Research News. 2014.

[21] Khalid A, Manshoor B. Analysis of mixture formation and flame development of diesel combustion using a rapid compression machine and optical visualization technique. Applied Mechanics and Materials: Trans Tech Publ; 2013. p. 293-8.

[22] Khalid A. Effect of ambient temperature and oxygen concentration on ignition and combustion process of diesel spray. Asian Journal of Scientific Research. 2013;6(3):434-44.

[23] Khalid A, Manshoor B. Effect of high swirl velocity on mixture formation and combustion process of diesel spray. Applied Mechanics and Materials: Trans Tech Publ; 2012. p. 695-9.

[24] Sathiyamoorthi R, Sankaranarayanan G. Fuel injection timings of a direct injection diesel engine running on neat lemongrass oil-diesel blends. International Journal of Automotive and Mechanical Engineering. 2015;11:2348-63.

[25] Khalid A, Jaat N, Sapit A, Razali A, Manshoor B, Zaman I, et al. Performance and emissions characteristics of crude jatropha oil biodiesel blends in a diesel engine. International Journal of Automotive and Mechanical Engineering. 2015;11:2447-57. 
[26] Khalid A, Mustaffa N, Manshoor B, Zakaria H, Alimin AJ, Leman AM, et al. The comparison of preheat fuel characteristics of biodiesel and straight vegetable oil. Applied Mechanics and Materials: Trans Tech Publ; 2014. p. 161-6.

[27] Ma F, Hanna MA. Biodiesel production: A review. Bioresource Technology. 1999;70:1-15.

[28] Vashist D, Ahmad M. Statistical analysis of diesel engine performance for castor and jatropha biodiesel-blended fuel. International Journal of Automotive and Mechanical Engineering. 2014;10:2155-69.

[29] Nayak C, Pattanaik BP, Nayak SK. Effect of preheated jatropha oil and jatropha oil methyl ester with producer gas on diesel engine performance. International Journal of Automotive and Mechanical Engineering. 2014;9:1709-22.

[30] Hasan MM, Rahman MM, Kadirgama K. A review on homogeneous charge compression ignition engine performance using biodiesel-diesel blend as a fuel. International Journal of Automotive and Mechanical Engineering. 2015;11:2199211.

[31] Mustaffa N. Effects of biodiesel fuel temperature on performance and emissions of a compression ignition (CI) engine. Master thesis, Universiti Tun Hussein Onn Malaysia; 2013.

[32] Khalid A, Jaat CYM, Zaman I, Manshoor B, Ali M. Effect of preheated fuel on mixture formation of biodiesel spray. Applied Mechanics and Materials: Trans Tech Publ; 2013. p. 493-8.

[33] Mohod TR, Bhansali S, Moghe S, Kathoke T. Preheating of biodiesel for the improvement of the performance characteristics of di engine: A review. International Journal of Engineering Research and General Science. 2014;2:74753.

[34] Naima K, Liazid A. Waste oils as alternative fuel for diesel engine: A review. Journal of Petroleum Technology and Alternative Fuels. 2013;4:30-43.

[35] Nursal RS, Khalid A, Tajuddin A, Syukri A. Performance and emissions characteristics of alternative biodiesel fuel on small diesel engine. Energy Procedia. 2015;18:1317-34.

[36] Rahim R, Mamat R, Taib MY, Abdullah AA. Influence of fuel temperature on diesel engine performance operating with biodiesel blend. Journal of Mechanical Engineering and Sciences. 2012;2:226-36.

[37] Shahid S, Minhans A, Puan OC. Assessment of greenhouse gas emission reduction measures in transportation sector of malaysia. Jurnal Teknologi. 2014;70:1-8.

[38] Sharma S, Singh R, Mishra M, Mitra GK, Gangwar RK. Performance and emission analysis of diesel engine using biodiesel and preheated jatropha oil. International Journal of Current Research and Academic Review. 2014;2(60:22939.

[39] Khalid A, Hayashi K, Kidoguchi Y, Yatsufusa T. Effect of air entrainment and oxygen concentration on endothermic and heat recovery process of diesel ignition. SAE Technical Paper no. 2011-01-1834.

[40] Khalid A, Tomoaki Y, Takayuki M, Jun K, Yoshiyuki K. Analysis of relation between mixture formation during ignition delay period and burning process in diesel combustion. SAE Technical Paper no. 2009-32-0018. 